\title{
7. SEDIMENTARY AND DIAGENETIC STRUCTURES AND TEXTURES IN TURBIDITIC AND HEMITURBIDITIC STRATA AS REVEALED BY WHOLE-CORE X-RADIOGRAPHY, MIDDLE VALLEY, NORTHERN JUAN DE FUCA RIDGE ${ }^{1}$
}

\author{
Catherine A. Rigsby, ${ }^{2}$ Robert A. Zierenberg, ${ }^{3}$ and Paul A. Baker ${ }^{4}$
}

\begin{abstract}
Whole-core X-radiography of siliciclastic and clastic sulfide strata from Middle Valley, northern Juan de Fuca Ridge revealed primary, biogenic, and diagenetic structures and textures that were not evident during visual core examination. These textures and structures document a history of fine-grained turbidite sedimentation overprinted by several phases of carbonate and sulfide diagenesis. The X-radiographs reveal primary sedimentary structures in mud-rich units that allow us to distinguish between mud turbidites and pelagic deposits. They reveal three distinct ichnofauna assemblages that record depositional environments with different levels of oxygen and different sedimentation rates as well as eight major carbonate and pyrite diagenetic morphologies. The X-radiographs delineate the extent of metalliferous turbidites and debris flows at Site 856. Further analysis of the structures and textures illuminated by X-radiographic techniques will permit detailed interpretations of the sedimentary and diagenetic history of sedimentation in this sedimented rift valley.
\end{abstract}

\section{INTRODUCTION}

Late Pleistocene to Holocene sediments were recovered from four sites in Middle Valley, a sediment-filled axial rift of the Juan de Fuca Ridge (Fig. 1). These sediments are dominated by fine-grained turbidites that record depositional, thermal, and tectonic events in this sedimented ridge environment. Many of the depositional and diagenetic aspects of the sediments were not readily visible during routine shipboard core examination.

Several months following the leg, cores from Holes 856A, 856B, $857 \mathrm{~A}, 858 \mathrm{~A}$, and $858 \mathrm{~B}$ were $\mathrm{X}$-rayed at the Ocean Drilling Program (ODP) core repository in College Station, Texas. X-radiography revealed previously unobserved sedimentary, biogenic, and diagenetic textures and structures, allowed us to distinguish between distal mud turbidites and pelagic sediments, and improved our understanding of carbonate and sulfide diagenesis in these cores.

The purpose of this paper is to briefly document the methods and results of our post-cruise study and to establish the usefulness of $\mathrm{X}$-radiography as a routine tool for shipboard analysis of sedimentary cores. Although X-radiography is a common technique in the analysis of recent sediments, it has seldom been applied to studies of deep drill cores. The work presented here suggests that X-radiography of split cores is a valuable tool for observing, analyzing, and interpreting the origins of textures and structures in drill cores.

\section{METHODS}

A portable industrial X-ray unit was available at the ODP core repository at Texas A\&M University in College Station. The unit is modified to accept an entire $150-\mathrm{cm}$ section of split core, but the length of section that could be covered in a single exposure was limited to $25 \mathrm{~cm}$. Most of the sediment sections were placed in the lead-lined protective chamber and exposed for 150 to 200 seconds at $90 \mathrm{KV}$ using standard medical X-ray film. Sulfide-rich sections were exposed for 100 to 150 seconds at $90 \mathrm{KV}$. Initial tests found these exposure times and voltages to be appropriate for most of the cases. The quality of X-ray images is greatly degraded by variations in

\footnotetext{
${ }^{1}$ Mottl, M.J., Davis, E.E., Fisher, A.T., and Slack, J.F. (Eds.), 1994. Proc. ODP. Sci. Results, 139: College Station, TX (Ocean Drilling Program).

${ }^{2}$ Department of Geology, East Carolina University, Greenville, NC 27858, U.S.A

${ }^{3}$ U.S. Geological Survey, Menlo Park, CA 94025 , U.S.A.

${ }^{4}$ Department of Geology, Duke University, Durham, NC 27706, U.S.A.
}

sample thickness. Several attempts were made to fashion a core holder similar to that described by Bouma (1969) that would correct for the change in thickness across the half-round sections. The design of the X-ray unit, however, prohibited the effective use of such a device. The images obtained are best near their centers, where the core is at maximum thickness. Many of the images were later computer-corrected for edge effects.

The developed images were scanned into digital format using an Envisions ENV6000 scanner with a full-page transparency attachment and were analyzed using personal computers and commercial and public domain image-analysis and photo-retouching software (NIH image analysis programs, Adobe Photoshop, and Micrografx Picture Publisher). The individual $25-\mathrm{cm} \mathrm{X-radiographs} \mathrm{typically}$ took 11 megabytes (MB) of storage space when scanned at 600 dpi (4 $\mathrm{MB}$ at $300 \mathrm{dpi}$ and $1.5 \mathrm{MB}$ at $150 \mathrm{dpi})$. Scan speed and resolution were varied depending on the detail needed for individual analyses. The data were compressed and stored on $88 \mathrm{MB}$ Syquest cartridges.

\section{X-ray Prints}

The hydraulically piston-cored samples from Holes $856 \mathrm{~A}, 856 \mathrm{~B}$, $857 \mathrm{~A}, 858 \mathrm{~A}$, and $858 \mathrm{~B}$ were $\mathrm{X}$-rayed, resulting in $1141 \mathrm{X}$-radiographs, each covering $25 \mathrm{~cm}$ of core. Most of the images were scanned and stored in tagged image file format (TIFF) on Syquest cartridges. The files can be read by both IBM-compatible and Macintosh personal computers with image handling capability. The $\mathrm{X}$-radiographs reproduced in this chapter are prints of those TIFF files. They are printed as negative X-ray images, so that the brighter the image, the denser and more opaque the material to the passage of X-rays. Bright white elliptical and elongate bodies, for example, are opaque and dense iron sulfides and carbonates. Solid black areas are open cracks and fractures. Cracks and fractures caused by coring disturbance are easily distinguished from natural, low-density units in the cores.

\section{RESULTS}

Visual core examination revealed that all of the strata recovered by Leg 139 can be categorized into three basic lithotypes (Davis, Mottl. Fisher, et al., 1992): massive, hemipelagic silty clays and claystones; hemipelagic silty clays and claystones interbedded with turbiditic silts and siltstones and sands and sandstones; and massive, semimassive, and clastic sulfides. Of the cores recovered during Leg 139, Site 857 provides the most complete sedimentary sequence (with a cumulative 


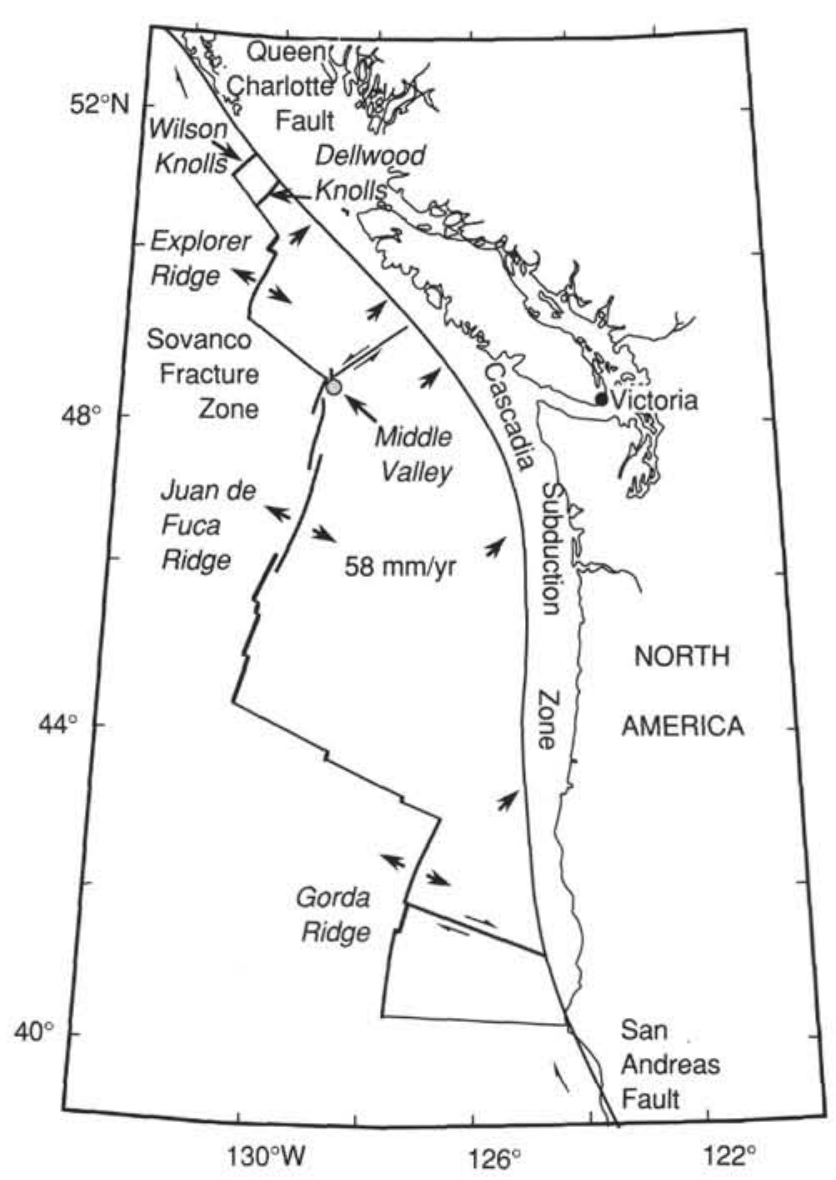

Figure 1. Location map showing the tectonic setting of the northern Juan de Fuca Ridge and the sedimented Middle Valley rift. Arrows indicate plate movement.

total of about $750 \mathrm{~m}$ penetrated [Langseth and Becker, this volume]), Site 858 provides the most continuous record of sediment alteration, and Site 856 provides the most complete suite of sulfide-rich sedimentary strata. Unaltered sands and sandstones at these sites are composed of quartz and plagioclase with chlorite, mica, amphibole, and clay as minor constituents, as identified by shipboard smear slide and X-ray diffraction (XRD) analysis and as verified by post-cruise petrographic studies. Alteration increases systematically with depth. At Site 858, biogenic components are completely leached out of the sediment even at shallow depths (at and below 110 mbsf in Hole 858 A and at and below 15 mbsf in Hole 858B). Below these depths, authigenic carbonates, sulfides, silicates, and anhydrite become increasingly common. Because of the presence of a wide range of macroscopic sedimentary and diagenetic structures and because of their relatively continuous record of sediment alteration, as identified by shipboard analysis, cores from Hole $858 \mathrm{~A}$ were chosen as the primary sedimentary section for preliminary X-radiographic analysis. Hole $856 \mathrm{~B}$ was chosen for the preliminary analysis of sulfide-rich sedimentary units.

All of the X-rayed Hole $858 \mathrm{~A}$ cores were characterized visually by shipboard and post-cruise examination as unconsolidated, hemipelagic sediments with minor fine-grained turbidites (to $139-858 \mathrm{~A}$ $3 \mathrm{H}-\mathrm{CC}, 30 \mathrm{~cm}$ ) or as interbedded hemipelagic to turbiditic sediments (Davis, Mottl, Fisher, et al., 1992). The latter sediments were further subdivided into an upper unconsolidated unit (to $139-858 \mathrm{~A}-5 \mathrm{H}-5$, $150 \mathrm{~cm}$ ) and a lower moderately to well-indurated unit (to 139-858A$8 \mathrm{H}-3,75 \mathrm{~cm})$. Hole $856 \mathrm{~B}$ cores X-rayed were visually characterized as moderately to well-indurated, hydrothermally altered hemipelagic and turbiditic sediments (to $139-856 \mathrm{~B}-3 \mathrm{H}-1,70 \mathrm{~cm}$ ) and slumped(?) hemipelagic, turbiditic, and clastic sulfidic sediments (to 139-856B$4 \mathrm{H}-5,150 \mathrm{~cm})$.
A

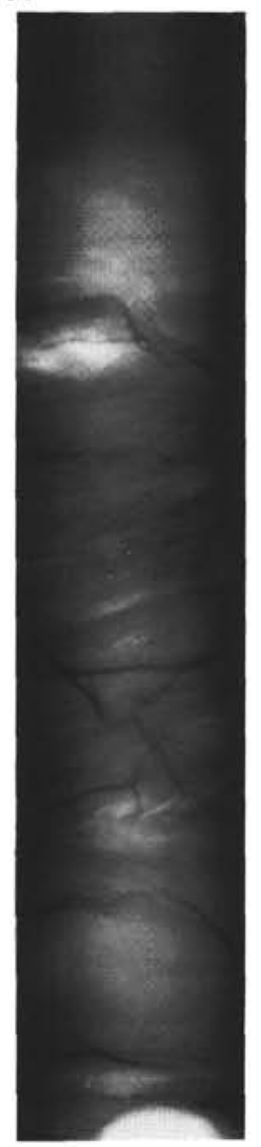

B

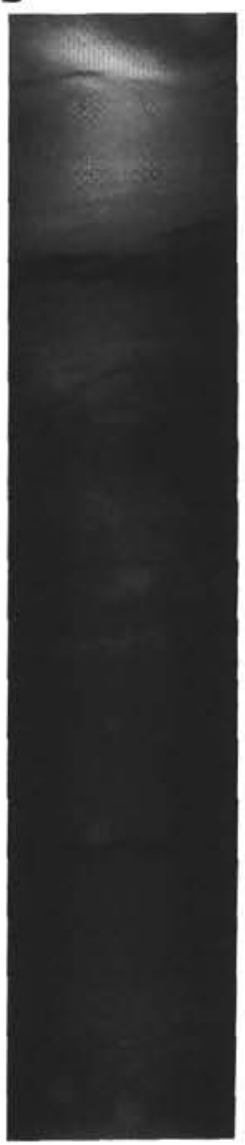

C

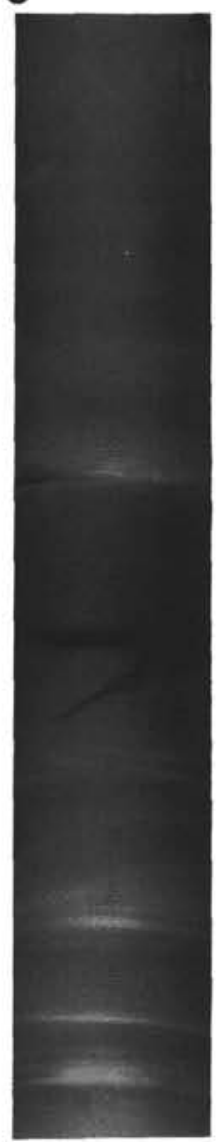

Figure 2. X-radiographs of Middle Valley turbiditic strata showing typical primary sedimentary structures. A. Sample $139-858 \mathrm{~A}-5 \mathrm{H}-4,50-75 \mathrm{~cm}$. Amalgamated fine-grained sandstone and siltstone bedsets exhibiting high-angle cross-laminations and parallel laminations. Note the sharp scour surfaces at 64 and $68 \mathrm{~cm}$. B. Sample 139-858A-5H-3, 100-125 cm. Wavy laminations in a fine-grained sandstone and siltstone turbidite. The presence of diagenetic carbonate at the top of the underlying mudstone masks a sharp contact at the base of the upper turbidite. C. Sample 139-858A-1H-4, 25-50 cm. Parallel and subhorizontal laminations in a distal silty turbidite sequence.

\section{Primary Sedimentary Structures and Sequences in Siliciclastics}

One of the principal goals of this work was to use X-radiography to distinguish between pelagic strata and very fine-grained turbiditic sequences in Leg 139 cores, a distinction that could not be made during visual core examination. Sediments above 21.4 mbsf (858A-3H-CC, $30 \mathrm{~cm}$ ) in Hole $858 \mathrm{~A}$ contain rare redeposited neritic and upper bathyal fauna; visual examination reveals few silty or muddy turbidite sequences. These strata were interpreted as predominantly hemipelagic (Davis, Mottl, Fisher, et al., 1992). Below 21.4 mbsf, no redeposited fauna are present and the strata are visually characterized as stacked Tbcde or Tcde turbiditic sequences with sharp basal contacts overlain by massive or parallel-laminated fine sands that grade upward into nonturbiditic clay or claystone. There is an average of three turbidite sequences per meter of core and the sand/mud ratio becomes higher downcore. At the top of Hole $858 \mathrm{~A}$, the sand/mud ratio is approximately 1:10; at the base of the sedimentary sequence ( $249.7 \mathrm{mbsf})$ it is approximately 1:2 (Davis, Mottl, Fisher, et al., 1992). The X-ray images of these strata reveal primary sedimentary structures in mudrich units that were previously interpreted as pelagic, thus allowing us to distinguish between mud turbidites and hemipelagic muds. 
Strata that are unequivocally turbiditic exhibit a range of primary sedimentary structures including low- and high-angle cross-laminations, parallel laminations, and horizontal and subhorizontal laminations (Fig. 2). Individual turbidites are normally graded and typically have sharp, locally scoured bases (Figs. $2 \mathrm{~A}$ and $2 \mathrm{C}$ ). The grain size changes are seen in X-radiographs as gray-scale changes. The finegrained sands and the silts typically have lower porosities and bulk densities than the overlying muds and clays so that a fining-upward sedimentary sequence results in a darkening-upward X-ray image.

True pelagic strata are rare in these cores. Pelagites show up as dark, intensely bioturbated, locally laminated units on the X-radiographs. Most of the fine-grained strata that were visually interpreted as pelagic are revealed by X-radiography to be mud turbidites or, possibly, hemiturbidites (as defined by Stow and Wetzel, 1990). These mud units are extensively bioturbated, yet weak normal grading and sharp bases are commonly preserved (Fig. 3B). They were probably deposited slowly from the distal end of turbidity current suspension clouds.

\section{Biogenic Structures and Textures}

$\mathrm{X}$-ray images are extremely useful for studying bioturbation in sediments. In Leg $139 \mathrm{X}$-radiographs, burrows are especially easy to identify because they are typically filled or lined with either authigenic calcite or pyrite (discussed below). The X-radiographs reveal a wide range of bioturbation intensity, from unbioturbated to thoroughly homogenized. In addition, a range of distinctive trace fossils is present.

Vertical burrows indicative of specific ichnotaxa occur in several distinct morphologies. Simple vertical burrows, such as those in Fig. 3B are characteristic of Skolithos. Small, branching burrows (Figs. 3A, 3C, 3D, and 4) are the ichnofossil Chondrites. Large twisting and branching burrows such as those in Figure $3 \mathrm{~A}$ are common in these strata while horizontal traces are less common. Rare, small horizontal burrows are confined to the silty and sandy intervals (Fig. $3 \mathrm{H}$ ), whereas large horizontal Zoophycus burrows are typically confined to mud-rich units. Planolites and Thalassinoides traces are also common through the mud-rich intervals. Phycosiphon is common locally within silty and muddy turbidites.

This assemblage of ichnofauna has several different patterns of occurrence in these cores. Ichnofauna assemblages in deep marine strata are indicators of many environmental variables, including differences in sediment accumulation rates, oxygen levels, and depositional environments (Ekdale et al., 1984; Wetzel and Wijayananda, 1990). Thick-bedded, sandy turbidites are seldom bioturbated because they accumulate rapidly and because they drastically change the substrate, making long-term adaptation difficult for the benthic infauna. Fine-grained turbidites that accumulate rapidly may not be bioturbated if sediment accumulation rates exceed biological reworking rates. However, when sedimentation rates and reworking rates are in equilibrium, fine-grained turbidites may be extensively bioturbated. Slowly accumulating pelagic strata in oxygenated environments are commonly burrowed.

Leg 139 strata contain three distinct faunal assemblages that record three different depositional situations. Where small-sized Skolithos, Planolites, Thalassinoides, Chondrites, and Zoophycus occur together in thin bioturbated sections (Fig. 4), a high oxygenation level and hemipelagic depositional conditions with relatively constant sedimentation rates are indicated (Berger et al., 1979; Wetzel and Wijayananda, 1990). In such cases, sediments accumulated slowly relative to bioturbation rates. Where Phycosiphon traces appear alone in relatively thick turbidite sequences (exceeding the penetration depth of individual burrows), bioturbation under conditions of rapid sediment accumulation is indicated (Wetzel and Wijayananda, 1990). Such conditions were not observed in the X-radiographs, but are common in deeper, well-indurated cores described during visual examination (Davis, Mottl, Fisher, et al., 1992). Low-to-intermediate oxygen conditions (also observed in the deeper sections) may be indicated by assemblages of large-size Zoophycus, Planolites, and Chondrites and by sequences
A

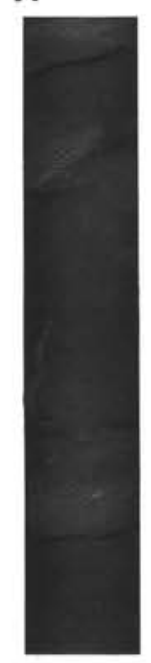

E

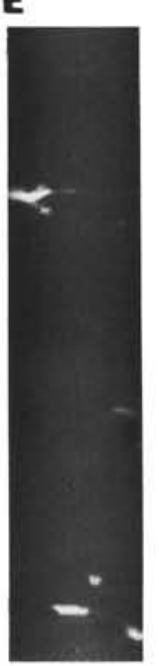

B

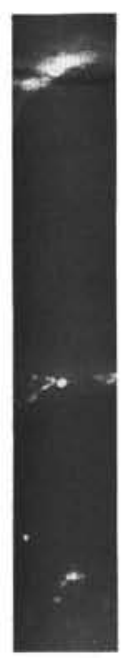

F

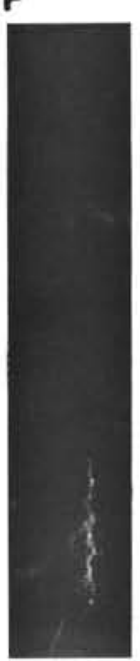

C

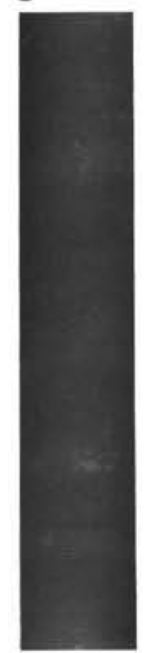

G

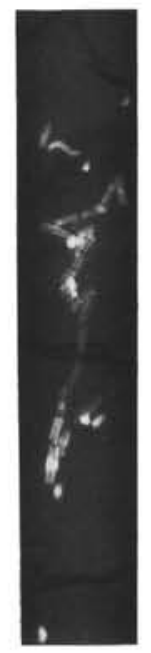

D

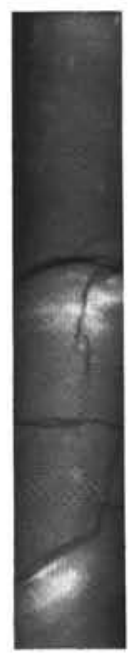

H

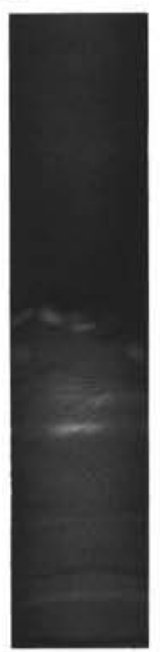

Figure 3. X-radiographs of Middle Valley core samples showing typical biogenic sedimentary structures. A. Sample $139-858 \mathrm{~A}-4 \mathrm{H}-6,100-125 \mathrm{~cm}$. Bioturbation in the clay-rich interval $(108-120 \mathrm{~cm})$ of a fine-grained distal turbidite. The large vertical burrow is lined with calcite. The small, branched burrows near the top of the interval are Chondrites. B. Sample 139-858A-2H-4, $125-100 \mathrm{~cm}$. Typical mottled texture of a highly burrowed mud turbidite. Note the large subhorizontal carbonate-filled burrow in the silty interval at 127-128 $\mathrm{cm}$, the carbonate nodules (burrow fills?) at $139-140 \mathrm{~cm}$, and the vertical Skolithos traces at $147-150 \mathrm{~cm}$. C. Sample $139-858 \mathrm{~A}-5 \mathrm{H}-2,25-50 \mathrm{~cm}$. Small, branched, carbonate-filled Chondrites burrows are present throughout this fine-grained distal turbidite. Note that carbonate-filled fractures $(40-44 \mathrm{~cm})$ are easily distinguished from burrows. D. Sample $139-858 \mathrm{~A}-6 \mathrm{H} 3,0-25 \mathrm{~cm}$. Small, locally branched chondrites burrows in the upper part of a silt-to-mud turbidite (0-13 cm.). E. Sample 139-858A-4H-6, 50-75 cm. Vertical, carbonate-filled burrows in hemipelagic mud with siltstone laminations. Similar vertical burrows are also present in F (Sample 139-858 A-4H-6, 75-100 cm.). G. Sample 139-856B-7H-2, 75-100 cm. Pyrite-lined vertical burrow (3 mm in diameter) that has been disrupted by sediment compaction. Also visible here are molds of bladed anhydrite crystals (e.g., at 90, 91, 92, 93, 99, and $103 \mathrm{~cm}$ ). H. Sample 139-858A-4H-5, 100-125 cm. Thoroughly homogenized clay-rich interval at the top of a turbidite sequence. Also note the rare horizontal burrow in the fine-sand turbidite at $121-123 \mathrm{~cm}$. 
A

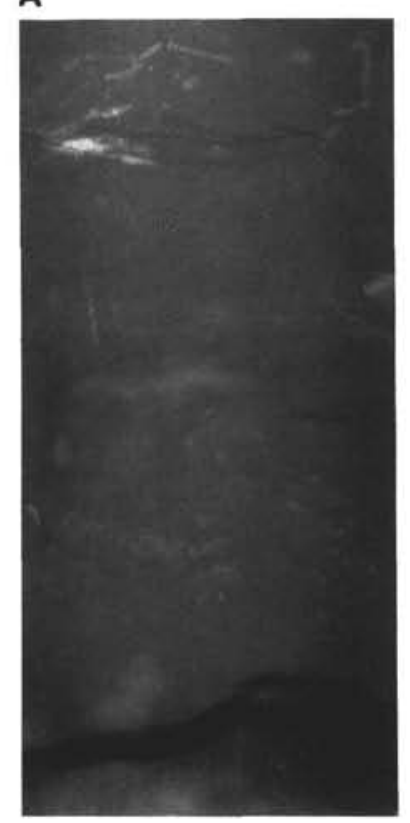

B

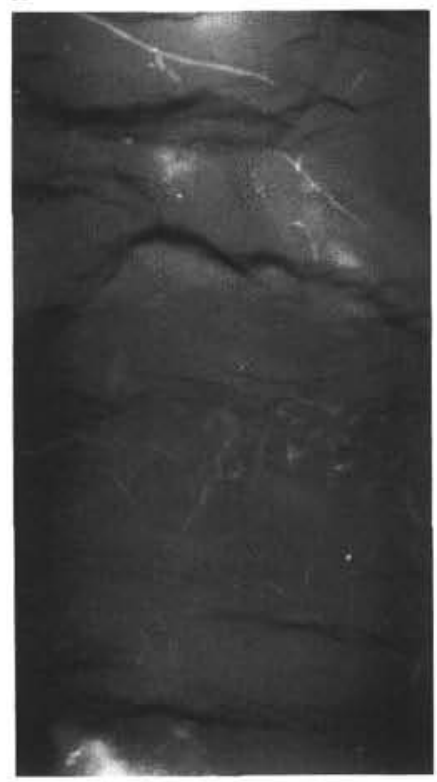

Figure 4. X-radiographs of Middle Valley hemipelagic and turbiditic mudstones showing burrow tiering structure. A. Sample 139-858A-6H-3, 124-135 cm. Intensely bioturbated hemipelagic mudstone containing Skolithos (S), Chondrites (C), Planolites (P), and Zoophycus (Z) trace fossils. Note the crosscutting relationships between the burrows. B. Sample 139-858A-7H-1, 139-148 cm. Turbiditic mudstone with Planolites and Thalassinoides (T) burrows reworked and cut by Chondrites burrows. Also note the presence of wider, pyrite-filled, subhorizontal burrows (unidentified) in the base of the overlying turbidite.

burrowed by Chondrites alone. Further work is necessary to adequately document changes in oxygen level and sedimentation rates recorded in Middle Valley strata.

In addition to the environmental information obtained from ichnofauna, we propose that the burrows disrupt the permeability structure of the sediments by acting as pipes for fluid migration through the sediments. Diagenetic pyrite and calcite both occur as lining and infilling material in the burrows. Many of the burrows are visible on the X-radiographs only because of the presence of these authigenic minerals. The burrowing obviously occurred in unconsolidated sediment within several $\mathrm{cm}$ of the seafloor (probably up to $20 \mathrm{~cm}$ in some cases). Pyritization of the burrows is also interpreted to have occurred near the sediment-water interface (see discussion below). Rarely, the larger pyritized burrows show evidence of disruption due to compaction of the sediment (Fig. 3G), confirming that they were pyritized early in the diagenetic history of the sediment. Some of the burrowfilling calcite, however, formed later in the diagenetic history, probably by in-situ precipitation from fluids migrating both vertically and laterally through the sediment.

\section{Diagenetic Structures and Textures}

Both diagenetic carbonate and diagenetic pyrite are easily recognizable in the X-radiographs but were commonly overlooked during routine shipboard sedimentological examination. Diagenetic carbonate, usually in the form of intergranular cement, is recognized because of its low porosity relative to the surrounding siliciclastic material. Likewise, high density sulfide minerals stand out in dramatic contrast to the surrounding sediments.

\section{Diagenetic Carbonate}

Four major diagenetic carbonate morphologies are present in the Leg 139 X-radiographs: burrow-linings and fillings (discussed above), mininodules, nodules, and laths. Small (millimeter-scale), well-rounded, spherical to slightly elliptical carbonate masses such as those seen in Figures 5A, 5B, and 5C are classified here as mininodules. Mininodules are common in the clay-rich intervals and differ from nodules in size only. Nodules are typically well-rounded, irregular spheres or elongated ellipsoids. They range from $5 \mathrm{~mm}$ to $3 \mathrm{~cm}$ in their longest diameter and occur most commonly in clay-rich intervals immediately adjacent to sandy or silty turbidites. Although nodule shape and location can be studied via visual core examination, X-radiography is useful for examining internal nodule structure and for determining overall nodule distribution. Figures $5 \mathrm{E}$ and $5 \mathrm{~F}$ show typical large nodules. The nodule in Figure 5E contains lath-shaped inclusions and textures that are reminiscent of the mininodules.

Nodules and mininodules in the upper part of the core (above about $20 \mathrm{mbsf}$ ) are formed as a result of microbially mediated methane oxidation within one or two meters of sediment-water interface. Deeper nodules and mininodules (below $20 \mathrm{mbsf}$ ) did not form as a result of methane oxidation. Although their textures are similar to those at shallower depths, their oxygen isotope compositions reveal that they formed at or near their present depths as a result of sulfate reduction of organic matter (Baker et al., this volume). It is likely that many of the large nodules formed as a result of continued precipitation and the eventual growing together of groups of mininodules. Mininodule formation may be related to the original distribution of carbonate microfossils in the fine-grained sediments. These hypotheses are currently under investigation.

Diagenetic laths are the fourth type of carbonate morphology revealed by X-radiography. The laths are up to $1 \mathrm{~cm}$ long and occur as individual features (Fig. 5F) or as multiple inclusions in nodules (Fig. $5 \mathrm{E})$. Although visual core examination reveals that anhydrite laths and molds are present in the core below $63 \mathrm{mbsf}$, we have no evidence to suggest that the laths revealed by X-radiography are anhydrite. They are typically 2 to 3 times larger than the visually observed anhydrite laths and occur at much shallower depths. Pore-water chemistry in the lath-bearing intervals (Davis, Mottl, Fisher, et al., 1992) suggests that the laths revealed by X-rays are calcite, not anhydrite. 
A

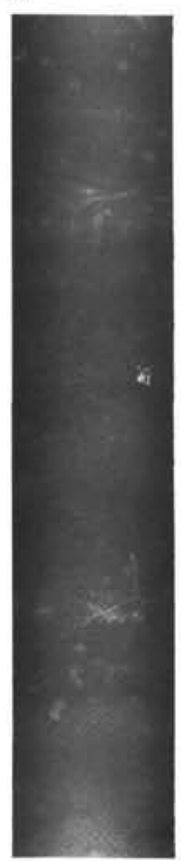

B

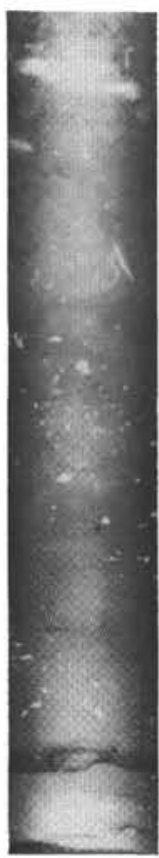

C

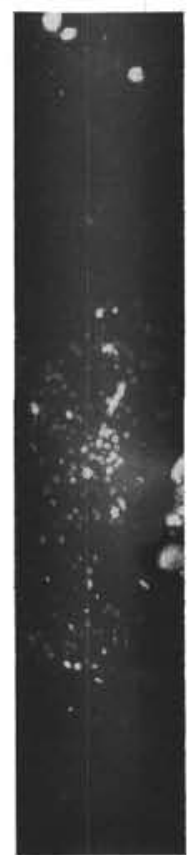

D

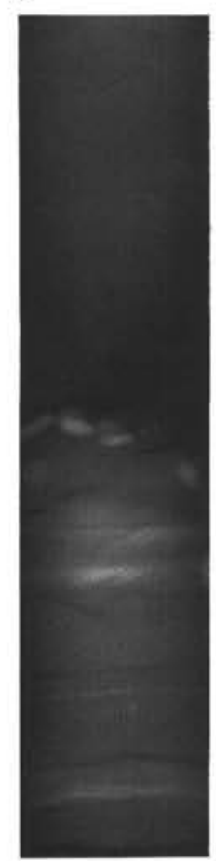

$\mathbf{E}$

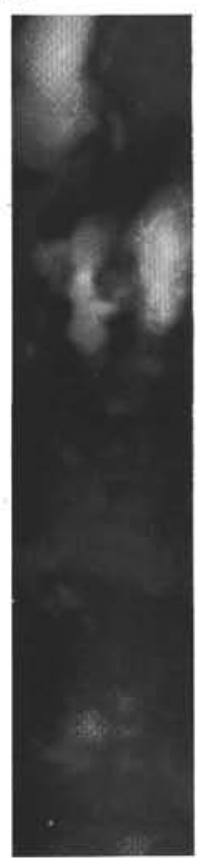

$\mathbf{F}$

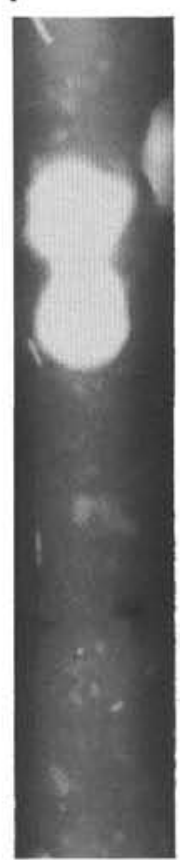

Figure 5. X-radiographs of Middle Valley diagenetic carbonate-rich strata. A. Sample 139-858A-5H-2, 25-50 cm. Light gray millimeter-scale mininodules in a silty clay distal turbidite. B. Sample 139-858A-7H-1, 50-75 cm. Note preferential concentration of mininodules in finer-grained (darker-colored) intervals. C. Sample 139-858 A-2H-6, 25-50 cm. Mininodules in silty claystone. Locally (near the top of the figure), mininodules coalesce to form small nodules. Also note the lath-shaped inclusion and the zoning of the small nodule at $39 \mathrm{~cm}$. D. Sample $139-858 \mathrm{~A}-4 \mathrm{H}-5,100-125 \mathrm{~cm}$. Elliptical nodules forming at the silt/mud contact in a turbidite sequence. Also note the small-scale cross-laminations at $115-117 \mathrm{~cm}$. E. Sample $139-858 \mathrm{~A}-2 \mathrm{H}-7,25-50 \mathrm{~cm}$. Large high-Mg calcite nodules in mudstone. The internal structure of the nodules is reminiscent of the mininodules in A, B, and C. Also note the lath-shaped inclusion in the nodule at $31 \mathrm{~cm}$. F. Sample $139-858 \mathrm{~A}-5 \mathrm{H}-7,25-50 \mathrm{~cm}$. Large calcite nodule and small lath-shaped carbonate in hemipelagic mudstone.

\section{Diagenetic Pyrite}

Pyrite commonly occurs as burrow-lining and burrow-filling material (discussed above), as nodules in clay-rich sediment, and as disseminated grains that are preferentially concentrated in the silty portions of turbidites (Fig. 6). Pyrite nodules range from submillimeter to centimeter size and are typically ovoid and flattened in the plane of sediment bedding (Fig. 6B). Disseminated pyrite is most common in silt-rich layers of turbidites, particularly where these layers form the basal bed of a turbidite sequence (Figs. 6C and 6D). Disseminated pyrite in the silty layers often coalesces into poikiolitic nodules of pyrite that incorporate the silt grains. Examination of these pyrite-rich layers in polished thin section shows that the paragenetically earliest mineralization is often evident as poorly developed pyrite framboids sparsely disseminated in the mud matrix of the silt beds. Most of the pyrite occurs as anhedral pore-fillings between the silt grains. As the abundance of pyrite increases, these patches of interstitial pyrite coalesce into nodules of massive pyrite that completely replace the matrix between the incorporated silt grains. Late-stage euhedral pyrite often nucleates on these nodules so that their exteriors are decorated by crystal faces.

We speculate that the preferential development of pyrite in the silty laminae is controlled by a combination of enhanced permeability and chemically reactive substrate. Sandy portions of the turbidites have adequate permeability to allow diffusion of sulfate-bearing pore fluid, but apparently lack either sufficient organic matter to drive sulfate reduction or sufficient reactive iron sources (for example, iron oxide coatings on clay particles) to form significant accumulations of pyrite. Clay-rich sediment may not have sufficient permeability to resupply sulfate-bearing pore water to the sites of reduction, except in the microenvironment provided by burrowing organisms. Silty turbidite layers with a clay matrix appear to maximize the potential for sulfate-reduction coupled with pyrite precipitation.

\section{Clastic Sulfide}

$\mathrm{X}$-radiography of the cores was particularly useful in delineating the extent of metalliferous turbidites and debris flows in cores from Hole $856 \mathrm{~B}$ (Fig. 7). The source of the clastic sulfide and oxide material that forms the metalliferous sediments in this hole is a $35-\mathrm{m}$-high, east-west trending ridge of weathered massive sulfide exposed at the seafloor $150 \mathrm{~m}$ south of Hole $856 \mathrm{~B}$. The first interval of metalliferous sediment occurs in Sample 139-856B-4H-3, 32-39 cm (25.7 mbsf) and continues interbedded in the sedimentary section up to $856 \mathrm{~B}-3 \mathrm{H}$ $5,70-85 \mathrm{~cm}$ ( $18 \mathrm{mbsf})$. The $\mathrm{X}$-radiographs show that the metalliferous sediment occurs in discrete beds from a few centimeters to tens of centimeters thick. Many of these beds are well-defined turbidites that show sharp basal contacts and an upward decrease in metalliferous component (indicated by decreasing opacity to the X-rays; Fig. $8 \mathrm{~A})$. Some of the thicker beds are chaotic or lack internal structure and contain angular clasts of massive sulfide (Fig. 8B). They are interpreted to be sulfide-rich debris flows. The amount of metalliferous sediment, as well as the thickness and frequency of the metalliferous beds, increases upward through the 7.7-m-thick interval. Some of the metalliferous sediment beds have diffuse top and bottom contacts. Some of the depositional contacts were disrupted during coring, but others may have been disturbed by bioturbation, which mixed metalliferous sediment into the underlying sediment.

Examination of both X-radiographs and the core indicates that some sulfide formed by authigenic growth in the sediment. This sulfide occurs as fine-grained crystals disseminated throughout metalliferous sediment and as crystal coatings on fracture and parting surfaces. No evidence for in-situ hydrothermal precipitation of sulfide, such as crosscutting veins of sulfide, was observed. We were also unable to recognize any laminae of sulfide that might suggest deposition of particulate sulfide from hydrothermal plumes above active 
Figure 6. X-radiographs of Middle Valley cores showing typical occurrences of diagenetic pyrite. A. Sample 139-858A-7H-5, 74-100 cm. Disseminated pyrite in silt laminations. B. Sample 139-858A-7H-4, 98-124 cm. Disseminated pyrite in silty turbidites. Note the massive pyrite nodule in the lamination at $122 \mathrm{~cm}$. C. Sample

$139-858 \mathrm{~A}-8 \mathrm{H}-2,75-103 \mathrm{~cm}$. Fine-grained disseminated pyrite in a laminated silty turbidite. Note the absence of pyrite in the clay-rich interval from $77-83 \mathrm{~cm}$. Also note the large pyrite nodule at the base of the figure. Individual, euhedral pyrite grains are clearly visible within the nodule. D. Sample

139-858A-7H-3, 49-77 cm. The sandy turbidite base in the upper part of the figure is highly pyritic. Note that the only pyrite present in the fine-grained (dark-colored) interval is burrow-fill material.

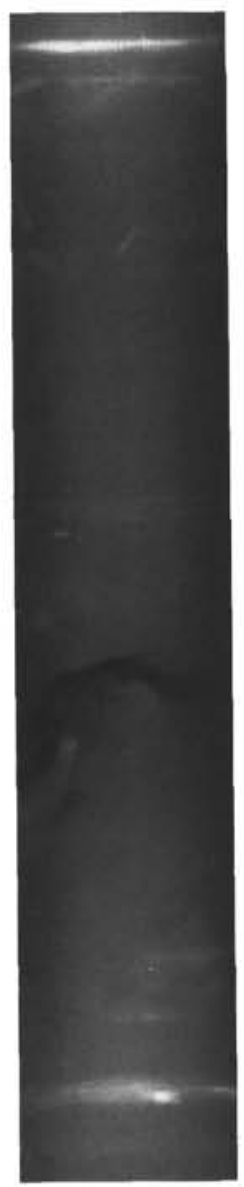

A

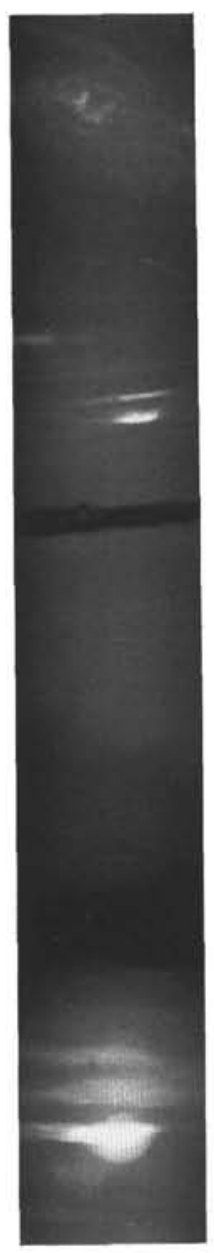

B

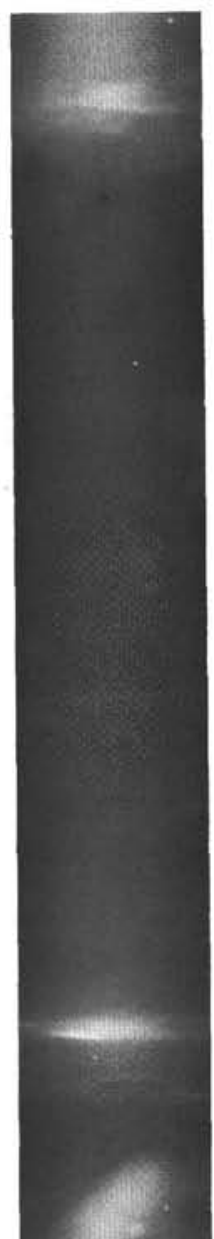

C

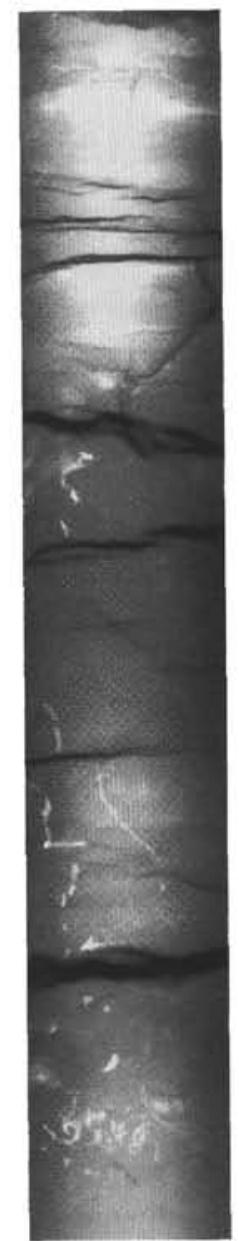

D vents. All of the observed features suggest that the metalliferous sediment was transported as clastic grains to the site of deposition.

The metalliferous sediment is composed of mixtures of hematite, magnetite, pyrite, and hydrothermal smectite with less abundant chalcopyrite, sphalerite, amorphous silica, and barite. The abundance of iron oxide and the porous and weathered nature of many of the clasts suggest that material for the metalliferous sediment formed by seafloor oxidation and weathering of the massive sulfide deposit $150 \mathrm{~m}$ south of the depositional site. The increase in both the thickness of metalliferous beds and in the size of sulfide clasts upward through this section suggests that the degree of disaggregation and weathering of the massive sulfide deposit was the primary control on the availability of material for forming the redeposited metalliferous sediment. These units therefore primarily record the destruction of this seafloor deposit, not its construction. The presence of authigenic sulfide in these sediments is interpreted to result from local sulfate reduction utilizing the abundant reactive iron-oxide component in these sediments and does not appear to be an indication of local hydrothermal precipitation of sulfide.

Hole 856B was drilled on the flank of an uplifted sediment hill. The sediment interval containing the metalliferous sediment is anomalous because of the dipping contacts of the sediment layers (e.g., Fig. 8) and has been interpreted as a slumped interval (Davis, Mottl, Fisher, et al., 1992). The sudden cessation of metalliferous turbidite deposition at $18 \mathrm{mbsf}$ recorded by the $\mathrm{X}$-radiographs may have been caused by the sudden uplift of this section of the seafloor above the local depositional basin that was receiving debris from the steep weathering ridge of massive sulfide.

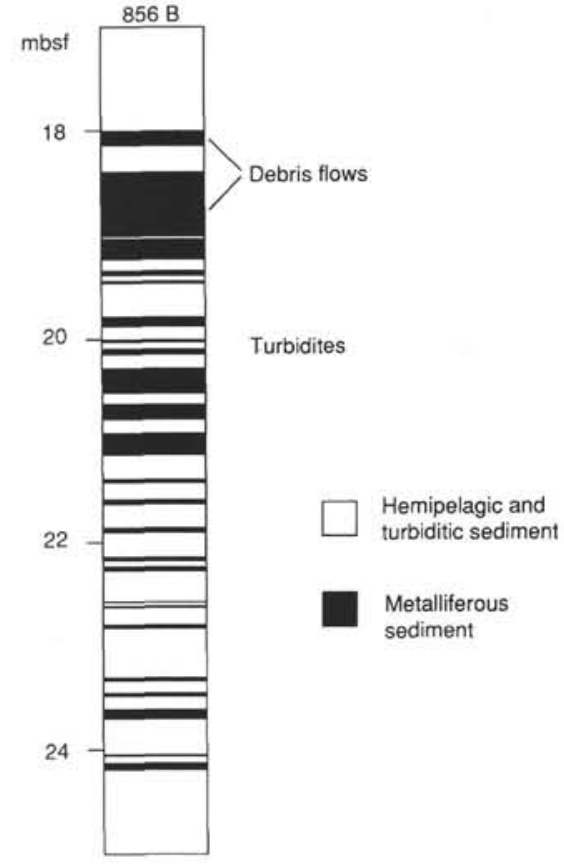

Figure 7. Schematic section of Core $856 \mathrm{~B}(856 \mathrm{~B}-3 \mathrm{H}-5,70 \mathrm{~cm}$ through $856 \mathrm{~B}-$ $4 \mathrm{H}-3,39 \mathrm{~cm}$, between approximately 18 and $26 \mathrm{mbsf}$ ) showing the extent of metalliferous sediment. Samples containing metalliferous sediment thicken and coarsen upsection. 
A

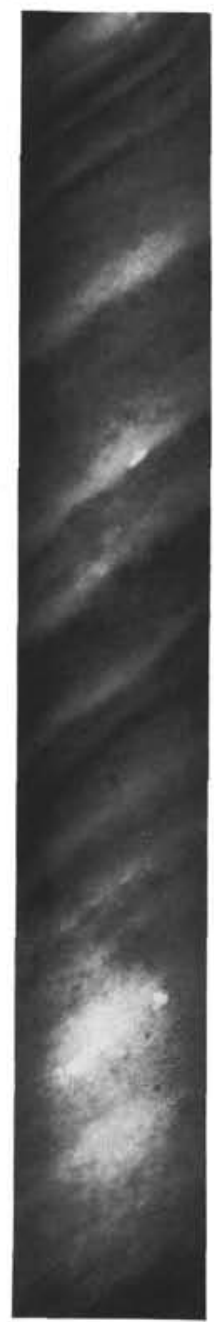

B

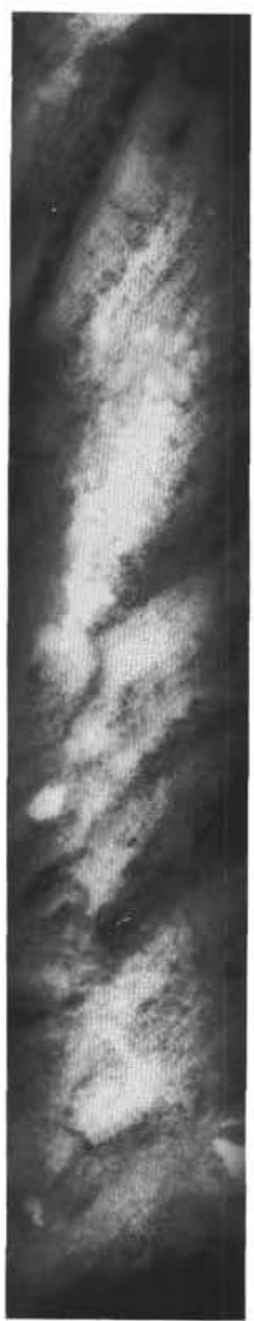

\section{CONCLUSIONS}

The X-radiographs taken for this study show many structures and textures that were not observed in the core during visual examination. Much of what we see, however, is as yet unidentified because the $\mathrm{X}$-radiography was done after the core was described. X-radiographs serve as a guide to our continuing studies by providing a sampling guide, by enabling us to make volume estimates of diagenetic mineralization, and by providing a clear picture of the processes that were responsible for both stratal accumulation and alteration.

To be truly effective in improving core description and guiding sampling, X-radiography should be done aboard the Resolution as part of routine core analysis.

\section{ACKNOWLEDGMENTS}

We are grateful to Chris Mato and the staff at the ODP core repository at TAMU for assisting with core access and equipment setup and to the ODP photography group for helping with film selection and logistics. We also thank the veterinary staff at the TAMU veterinary facility for providing access to and instruction in the use of their X-ray developing equipment. Funding for this study was provided by a JOI/USSAC grant to Rigsby.

\section{REFERENCES}

Berger, W.H., Ekdale, A.A., and Bryant, P.P., 1979. Selective preservation of burrows in deep-sea carbonates. Mar. Geol., 32:205-230.

Bouma, A.H., 1969. Methods for the Study of Sedimentary Structures: New York (Wiley-Interscience).

Davis, E.E., Mottl, M.J., Fisher, A.T., et al., 1992. Proc. ODP, Init. Repts., 139: College Station, TX (Ocean Drilling Program).

Ekdale, A.A., Bromley, R.G., and Pemberton, S.G. (Eds.), 1984. Ichnology: Trace Fossils in Sedimentology and Stratigraphy. SEPM Short Course, 15.

Stow, D.A.V., and Wetzel, A., 1990. Hemiturbidite: a new type of deep-water sediment. In Cochran, J.R., Stow, D.A.V., et al., Proc. ODP, Sci. Results, 116: College Station, TX (Ocean Drilling Program), 25-34.

Wetzel, A., and Wijayananda, N.P., 1990. Biogenic sedimentary structures in outer Bengal Fan deposits drilled during Leg 116. In Cochran, J.R., Stow, D.A.V., et al., Proc. ODP. Sci. Results, 116: College Station, TX (Ocean Drilling Program), 15-24.

Figure 8. X-radiographs of Middle Valley clastic sulfide units. A. Sample 139-856B-3H-6, 25-50 cm. Closely spaced metalliferous sediment turbidites. Grading is displayed by the decrease in iron oxide and iron sulfide upward within each unit. Coarser turbidites also show grain-size grading, which is not apparent in the X-radiographs. Coarse clasts of massive sulfide occur at 32 , 39 , and $44 \mathrm{~cm}$. B. Sample 139-856B-3H-5, $125-150 \mathrm{~cm}$. Debris flow containing clasts of massive sulfide (bright) and sediment (dark). Bedding is chaotic on the scale of the core. Overlying debris flow at $70-85 \mathrm{~cm}$ is the uppermost unit of clastic sulfide and represents a sudden cessation of metalliferous sediment in a 7.7-m-thick sequence that coarsens and thickens upward.

\footnotetext{
- Abbreviations for names of organizations and publications in ODP reference lists follow the style given in Chemical Abstracts Service Source Index (published by American Chemical Society).
}

Date of initial receipt: 2 March 1993

Date of acceptance: 9 September 1993

Ms 139SR-224 